\title{
The Leitmotif of Expedition in Auden's Plays
}

\author{
S. Mohan
}

\begin{abstract}
Besides political and social themes, one finds the theme of Quest in the plays of W.H. Auden. It is a quest for several things: a quest for a new society as seen in The Dog Beneath the Skin, a quest for new human values as brought out in Paid on Both sides, a quest for new ideology as shown in the Dance of Death and a quest for a spiritual rebirth as exemplified in The Ascent of F6 ultimately leading to a quest for the realisation of self where it can 'fly alone To the alone (The Dance of Death, P.27). Above all he seems to believe strongly that the quest of modern man to establish a new world and a new life would be successful.
\end{abstract}

Keywords : realisation, spiritual rebirth, quest, quest of modern man.

\section{INTRODUCTION}

In Paid on Both Sides with the manipulation of Mortmere myth depicting the feud between the two mill owning families, Auden has reiterated his plea that the society which has lost its human values should be rectified and a new set of human values is seen here. Paid on Both Sides is a study of the perennial feud between two millowning families in the north of England. As the play commences joan bemoans the loss of her husband who has been killed in ambush by one of the spies and the feud continues until all are dead. The world presented in Paid on Both Sides is bereft of values. There are no laws, no policemen, no principles. " But here no remedy is to be thought of, no news but the new death" (Paid on Both Sides 17). One of the characters wants to get away from this sort of atmosphere. It is Dick, john's friend, getting disgusted with the feud and sickening atmosphere, decides to quit and tells his friend thus: "I have thought it all over and I think it is the best thing to do. My cousin writes that the ranch is a thoroughly good proposition. I don't know how I shall like the Colonies but I feel I must get away from the place is not merely an act of escapism from the predicament but also his wish to have access to a better congenial environment. Obviously Auden's oblique suggestion 16 for a set of new human values is made in the words of the chorus.

There is a time for Peace; too often we

Have gone on cold marches, have taken life,

Till! Wrongs are bred like files; the dreamer wakes

Who beats a smooth door, behind of footsteps.

On the left

The pointed finger, the unendurable drum,

To hear of horses stolen or a house burned.

Now this shall end with marriage as it ought;

Love turns the wind, brings up the salt smell.

Shadow of gulls on the road to the sea.

Revised Manuscript Received on December 20, 2019.

S.Mohan*, Department of English, Kalasalingam Academy of Research and Education, Krishnankoil, India. Email: smoha001@gmail.com

\section{ANALYSIS}

Though the search for peace and good human values is temporarily defeated, still the quest continues as the chorus says it:

Though he believe it, no man is strong.

He thinks to be calles the fortunate,

To bring home a wift, to live long.

But he is defeated; let the son

Sell the farm lest the mountain fall;

His mother and her mother won.

From a world of no values, to a world full of human values, the quest continues and the attempt at it is shown in the play it is suggested, that inspite of its initial failure, the quest continues.

The dance of death presents a quest for a new ideology. The old class should yield place to the new. Capitalism should give way to communism. In the very exposition itself the announcer makes it clear:

We present to you this evening a picture of the decline of a class, of now its members dream of la new life, but secretly desire, the old, for there is death inside them. We show you that death as a dancer.

The dancer in the plays takes on multifarious robes such as sun god, as demagogue, as the captain of the ship (of England) and finally as the Pilot, whose "ambition is no less than to reach the very heart of reality (The Dance of Death, 28). The change of the shift from one set of principles to another is made very clear by the announcer.

"We must have a revolution. But wait a moment. All this talk about class war won't get us anywhere. The circumstances here are quite different from russia. Russia has no middle class, no tradition of official administrative service. We must have an English revolution suited to English conditions, a revolution not to put one class on top but to abolish class, to ensure not less for some but more for all, a revolution of Englishmen for Englishman ... Down with the dictatorship of international capital (The Dance of Death 17.). Each time the dancer takes a new role, as the sun god, the demagogue, the captain and the pilot, he moves one step ahead on his quest for his new ideology. As Sun God he is the creator and destroyer, may be destroying the old and creating the new ones. As the demagogue, he preaches the new revolution and the chorus accept it and says,

The English revolution/ Is the only solution

We take a resolution/ to follow thee.

As the captain, he lead, the ship of England the chorus says,

The Ship of England crosses the ocean

Her sails are spread, she is beautiful in motion.

We love her and obey her captain's orders.

We know our mind, no enemy shall board us. 
And as the Pilot, he is involved in a Mystic flight' The chorus says,

This is something new

We don't know what to do

This doctrine is at variance,

With all our past experience

You may perhaps be right.

About this mystic flight.

The Announcer further says, "the greatest feat, the most stupendous risk in human history is being undertaken this evening by a gentleman who prefers to remain known simply as the the Pilot. His ambition is no less than to reach the very heart of Reality. " (The Dance of Death 27 - 28), Finally the dancer dies, leaving everything for the working class, The Announcer tells them what the Dancer leaves for them.

He leaves you his engines and his machines

The sum of all his productive means.

He leaves you 8 his railways, his liners and his banks

And he leaves you his money to spend with thanks.

A quest for new ideology seems to have been accomplished. One gets an impression that atleast a consciousness for that seems to have been created.

In the Dog Beneath the Skin, one sees his quest in a different form. It is a quest for a new society. The very title itself suggests it. The title has numerous connotations; it implies not merely the cryptic hidden animal nature of man, but also the corruption and sickness, which have been jeopardising the security of contemporary society. Alan Norman, the protagonist leaves his village, in search of the missing heir Francis. He is accompained by a wooly dog who is none other than Francis himself. Francis till the end remains in that disguise and has a comprehensive 'dog's eye view* of the society. Alan Norman and his dog Francis are taken through many 'worlds' such as, the corrupt monarchy in Ostnia, the dictatorship of westland, the redlight area with all its contamination, the lunatic asylum, a hospital and a luxury hotel. One is given a taste of all these things. The quest is, one can say, to have a new society, other than what has been presented in those 'worlds' when the Dog in the end speaks, he points out thus:

You see, I had begun to regard you in a new light. I was fascinated and horrified by you all. I thought such obscene, crue, hypocritical, mean vulgar creatures had never existed before in the history of the planet, and that it was my office and doom to record it. As a dog, I learnt with what a mixture of fear, bullying and condescending kindness you treat those whom you consider your inferiors, but on whom you are dependent for your pleasures. It's an awful shock to start seeing people from underneath. (The Dog Beneath the Skin 173).

Auden envisages a new society. Alan's journey through these worlds reflects the ills in the contemporary society, and finally his decision to quit his village is an allusion to the quest for a new society; perhaps he wants to go in search of a new society. The Dog explains why he wants to leave his village. He says,

"Since I've been away from you, I've come to understand you better. I don't hate you any more. I see how you fit into the whole scheme. You are significant, but not in the way I used to imagine. You are units in an immense

army; most of you will die without ever knowing what you leaders arc really fighting for or even that you are fighting at all. Well, I am going to be a unit in the army of the other side." (The Dog Beneath the Skin 176). And alan too joins him. And they both go in search of their quest for a new set up, a new society. As Frederick Buell puts it;

"As a short look at the play will confirm, it has for its theme the growth of Francis away from a Mortmerian fantasy role into the identity of a Marxist radical. Francis's a hometown Pressian Ambo is pure Mortmere, it is a rural English hamlet with an idyllic quality reminiscent of a fairy tale but marked in reality by a partially concealed inner rottenness. Francis' assumption of the dog's identity, then is similar to the 'gangs' withdrawal into the Rat's Hostel for he is simultaneously escaping from and engaged in observation and satire of the distortions of that society. Francis' decision to give up the identity of the dog for that of the political activist represents the culmination of whatever action the play has, his decision represents not only the casting off of his dog skin, the rejection of satirical withdrawal but also the exposing of Pressian, once and for all as anything but a fairy-tale world. Similarly the idea that holds all the episodes together is that of a quest ending in the inversion of the traditional fairy -tale goal; instead of Alan's having done pressian a service and having won thereby the hand of its princess, he finds that the princess is about to be married to a well known munitions manufacturer and that pressian is utterly ungrateful for his services." (Fredrick Buell 131-132)

By presenting a fairy-tale quest, Auden does not merely suggest a quest for a new society but a quest for something more than that As the title truly suggests, the society beneath the surface is different from the society that appears above the surface.

A different dimension of this quest theme is seen in On the Frontier. It is a quest for a new political life. The play presents the ills of the decadent corrupt monarchy as well as the oppressions of totalitarian rule. The quest is for a new political life, a new place, where life can go on smoothly; one of the characters longs for this longs for this life and he says:

In the place that I have found for us,

The place that I have hoped for since I was born

Born as well all are, into a world full of fear,

Where the faces are not the faces of the happy.

Where the disappointed hate the young

And the disinherited weep in vain.

Not that any are wanting this world, any;

The turckdriver, the executive setting his watch

The clerk entraining, for the office, us,

All of us wishing always it were different.

All of us wanting to be kind and honest,

Good neighbours and good parents and good children

To be beautiful and likeable and happy.

Ever since I was born I have been looking

Looking for a place where I

could really be myself

For a person who would see me

as I really am. 
And such a place he finds in the companionship of his lady-love which he makes use of in his escape from the real world of anarchy and destruction.

The play portrays war at national level; two countries, ostnia and Westland go to war, plunging both the countries into darkness. The king with his uncompromising fanatic attitudes and the Leader with his erratic and emotional declarations engager in war, perpetrating global destruction. What is wrought finally is nothing short of a cataclysm and a destruction of many lives. Violence is met with violence. Man's inescapable commitment th the world of violence is expressed by Auden thus:

Believing it was wrong to kill,

I went to prison, seeing myself,

As the sane and innocent student

Aloof among practical and violent madmen

But I was wrong. we cannot choose our world,

Our time, our class, None are innocent, none.

Causes of violence lie so deep in all our lives

It touches every act.

But hope is hinted at in the end. A new life where men can breathe happily every shown.

Europe lies in the dark

City and flood and tree:

Thousands have worked and work

To master necessity.

To build the city where

The will of love is done

And brought to its full flower

The dignity of man.

Finally a new life hitherto not seen in ther oppressed and totalitarian rules of monarchy and dictatorship, is hinted. With the removal of the monarchy and the dictatorship, a quest for new political set up where the dignity of man in its fulol flower is hinted at.

In the Ascent of F6, it is a quest for a spiritual rebirth which may lead for the realisation of self. F6 is the mountain, said to be hunted by a guardian-demon. Both British sudoland and Ostnian Sadoland prepare to claim it and the natives believe that the first white man who reaches the summit will be lord over both the countries. Michael Ransom does lead the expedition, not for any political reason but to satisfy his own reason and satisfy his own quest. He tries to conquer the ,ountain which stands for something unattainable. His mother's persuasion wins him.

There was a mother crucified herself

To save her favourite son from weakness,

Unlike his twin, his brother who depended

Upon the constant praises of the little.

She saved him nothing, he must have them too.

Because his brother had them.

She had died to-make him free.

(The Ascent of F6 47-48)

On the rock, in the final scene, the figure of Mrs, Ransom

stroking the hair of dead Ransom says.

And in the castle tower above,

The princess' cheek burns red for your love,

You shall be king and queen of the land,

Happy for ever, band in hand.

(The Ascent of F6 47-48)
Though the final scene is obscure, still one can deduce that it is a quest or certain spiritual values, and one does get a faint impression of this in the play.

Referring to these themes in general, Samuel Hynes remarks, "one clear feature of the thirties is that as the decade passed Englishmen became increasingly aware of the presence and importance of the world out there, as the abroad became a threat, it became a reality. In the case of young writers this meant a shift of attention away from English subjects, towards foreign scenes and. Problems..., there is also the journey itself, the ,most insistent of the thirties metaphors. As auden first composed it, it was a journey over the frontier, out of the familiar and secure into the unknown and frightening which has to be taken if one was to reach the new life. In the development of this mataphor in poems like paid on both sides and the magnetic Mountain details of landscape - the mountains, the Magnetic Mountain details of landscape the mountains, the pass, the rail-end take on symbolic meanings of a kind that can easily be adapted to actual geography. So one might say that the travel books simply act out in the real world the basic hope of the generation." (Samuel Hynes 228-229)

\section{CONCLUSION}

Auden has his own cause of the theme of the journeys and travels in his book. In his easy on 'Italian journey' he points out, " one reason why one enjoys reading travel books is that a journey is one of the archetypal symbols. It is impossible to take a train or an aeroplane without having a fantasy of oneself as a Quest hero setting off in search of an enchanted princess on the Waters of Life (W.H.Auden 135 ) this 'Quest -hero is seen in different ways in his plays.

\section{REFERENCES}

1. W.H.Auden, Forewords and Afterwords. New York, Random Book House, 1973.

2. Buell Frederick. W.H. Auden London: As A Social Poet, 1973.

3. Hynes Samuel. The Auden Generation Literature And Politics in England in the 1930 S London, 1976.

\section{AUTHORS PROFILE}

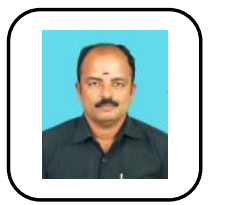

Dr. S. Mohan is an Associate Professor of the English Department at Kalasalingam Academy of Research and Education, Krishnankoil, Tamilnadu, India and is serving as Associate and Editorial Board member in more than eight International Journals. His areas of interest and research are in World Literatures, English Language Teaching and his main research area is African American Literature, which he formalized in his $\mathrm{PhD}$ (2013) on this subject. He has taught British, American, Indian Literatures and Literary Criticism in Post Graduate and Pre Doctoral Degree. He also taught Communicative English, English for Technical Communication for engineering graduates. He has presented papers at conferences, published articles and papers in various International journals. He has produced more than 25 M.Phil scholars and 04 $\mathrm{PhD}$ scholars are pursuing their research under his guidance. 